\title{
Pubic louse (Pthirus pubis) infestation of the scalp in a 4-years old infant
}

\section{Dört yaşındakı infantta skalpte pubik bit (Pthirus pubis) infestasyonu}

\author{
*Kosta Y. Mumcuoglu ${ }^{1}$ \\ ${ }^{1}$ Department of Microbiology and Molecular Genetics, Parasitology Unit, The Kuvin Center for the Study of Infectious and \\ Tropical Diseases The Hebrew University-Hadassah School of Medicine, Jerusalem, Israel \\ Corresponding author: Dr. Kosta Y. Mumcuoğlu, Parasitology Unit, Department of Microbiology and Molecular Genet- \\ ics, The Kuvin Center for the Study of Infectious and Tropical Diseases The Hebrew University-Hadassah School of Medi- \\ cine, Jerusalem 91120, P. O. Box 12272, Israel \\ E-mail: kostasm@ekmd.huji.ac.il \\ Received/Accepted: September 01, 2015/September 08, 2015 \\ Conflict of interest: There is not a conflict of interest.
}

\section{SUMMARY}

The pubic or crab louse (Pthirus pubis), is a parasitic insect spending its entire life on human hair and feeding exclusively on blood. Humans are the only known host of this parasite. Pubic lice usually infest a new host by close contact between individuals, making sexual contacts among adults and parent child interactions the more likely routes of infestation. We report the case of a 4year old male child, who was complaining from pruritus on the head area and around the eyes for several weeks. During the examination of the head, pubic lice and their eggs have been found on the eyelashes, eyebrows and scalp. The examination of other family members showed that the father but not the mother or the two bigger sisters were infested with pubic lice. The father was infested in the genital and chest area and apparently the child was often falling asleep on the chest of his father. For the treatment Hedrin Once (Dimethicone 4\%) was used, which was applied 3 times within 10 days. The follow up of the two patients several weeks later showed no living or dead lice on their scalp or body hair.

Keywords: Pthirus pubis, child, scalp infestation, phthiriasis palpebrarum

\section{ÖZET}

Pubik bit, insane kılında tüm hayatını geçiren ve kanla beslenen parasitic bir insekttir. İnsanlar bu parazit için konak olarak bilinirler. Pubik bit genellikle kişilerle yakın temas sonucunda bulaşırlar. Erişkinler arasındaki cinsel temas ve aile çocuk ilişkisi en olası infestasyon yollarıdır. Bir kaç haftadan beri baș bölgesinde göz etrafında kaşıntıdan yakınan 4 yaşındaki bir erkek çocuk olgusunu bildiriyoruz. Baș muayenesinde pubik bit ve yumurtaları, kaș, kirpik ve skalpte bulundu. Diğer aile üyelerinin muayenesinde babada (annede ve iki büyük kıkkardeşte değil) pubik bitlenme olduğunu gösterdi. Babanın pubik ve göğüs bölgesi bitlenmişti ve çocuk sıklıkla babasinın göğsünde uyuyordu. Tedavi için 10 gün boyunca günde üç kez dimetikon \%4 kullanıldı. İki hastanın takibinde iki hafta sonar saç ya da vücut kıllarında yaşayan ya da ölü bitler görülmedi.

Anahtar sözcükler: Pthirus pubis, çocuk, scalp infestasyonu, phthiriasis palpebrarum

\section{INTRODUCTION}

In addition to the head louse, Pediculus humanus capitis and the body louse, Pediculus humanus humanus mankind can also be parasitized by the pubic louse, Pthirus pubis, which causes the clinical picture of phthiriasis or pediculosis pubis. The pubic or crab louse is a parasitic insect spending its entire life on human hair and feeding exclusively on blood. Humans are the only known host of this parasite. Pubic lice usually infest a new host by close contact between individuals, making sexual contacts among adults and parent child interactions the more likely routes of infestation, than shared towels, clothing, beds or closets. Adults are more frequently in- 
fested than children ${ }^{1}$.

The main symptom is itching, usually in the pubic hair area. It results from hypersensitivity to louse saliva, and it becomes strong enough two or more weeks following initial infestation. In the majority of infestations a characteristic grey-blue or slate coloration appears (maculae caeruleae) at the feeding site, which may last for days. In adults, the pubic and axillary areas are those most commonly affected, however they can be also found in the perineum, thighs, lower legs, and trunk and in men the nipple areas, the upper arms, the wrist and even more rarely on the beard and moustache. In children infestation with pubic lice is rare and if such an infestation occurs, it is mainly concentrated on the eyelashes and eyebrows, which is known by the name phthriasis palpebrarum or pediculosis ciliarum. In this age-group pubic lice can be also found on the scalp. Perhaps one of the most ancient citations regarding the infestation of the scalp of a child is from Trouessart in 1891, who reported the case of a 5-months-old infant being infested on the eyelashes and the scalp behind the ears ${ }^{2}$. Cases of infants and young children infested with pubic lice on the eyebrows and eyelashes, the scalp, back, buttocks and chest hairs were most recently reported also by other authors ${ }^{1-5}$.

\section{CASE REPORT}

We report the case of a 4-year old male child, who was complaining from pruritus on the head area and around the eyes for several weeks. During the examination of the head, pubic lice and their eggs have been found on the eyelashes, eyebrows and scalp (Figure 1). The examination of other family members showed that the father but not the mother or the two bigger sisters were infested with pubic lice. The father was infested in the genital and chest area and apparently the child was often falling asleep on the chest of his father.

Within 10 days, father and child were treated 3 times with Hedrin Once (Dimethicone $4 \%$ ) on the infested areas. Thereafter, only dead lice and eggs still attached to the hair, could be seen. The follow up of the two patients several weeks later showed no living or dead lice on their scalp or body hair.

Figure 1: Pubic lice and nits on the scalp of the child.

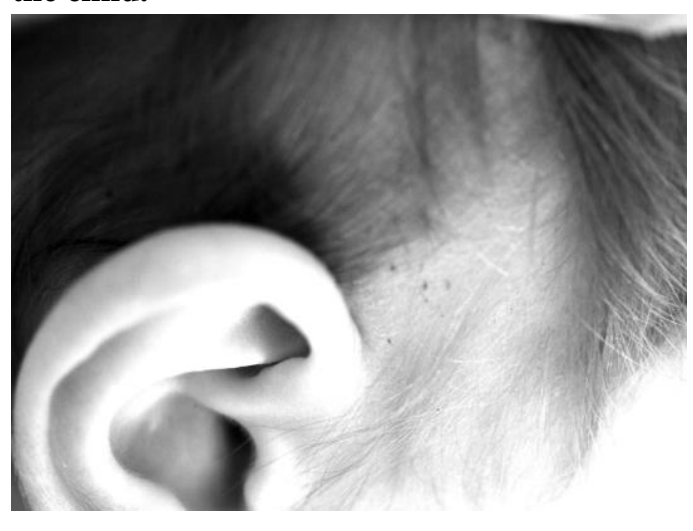

\section{DISCUSSION}

Pubic lice are primarily spread through sexual contact. Therefore, all partners with whom the patient has had sexual contact within the previous 30 days should be evaluated and treated, and sexual contact should be avoided until all partners have successfully completed treatment. Because of the strong association between the presence of pubic lice and sexually transmitted diseases (STDs) exists, patients diagnosed with pubic lice should undergo evaluation for other STDs, while infestation in a young child or teenager may indicate sexual abuse ${ }^{1}$.

In principle, any pediculicide which is effective against head lice could be used for the treatment of pubic lice, which are located on the body hair and scalp. The treatment of pubic lice on the eyelashes and eyebrows is somehow more complicated. It can be treated with a permethrin formulation by applying the solution to the infested hair with an applicator. A second treatment after 10 days is recommended. Other authors used yellow oxide of mercury or $0.25-1 \%$ physostigmine ophthalmic ointment, lindane, cryotherapy, argon laser and ivermectin ${ }^{5}$. It should be kept in mind that it is dangerous to remove lice or eggs from the eyelashes with forceps or scissors.

\section{REFERENCES}

1. Klaus S, Shvil Y, Mumcuoglu KY. Generalized infestation of a $31 / 2$ year-old girl with the pubic louse. Pediatr Dermatol 1994; 11: 26-8. 
2. Alexander JO'D. Arhtropods and Human Skin. Springer-Verlag, Berlin 1984; 422.

3. Elgart ML, Higdon RS. Pediculosis pubis of the scalp. Arch Dermatol 1973; 107: 916-7.

4. Aloi FG, Musso L. Phthiriasis pubis of the scalp in 2 children (in Italian). G Ital Dermatol Venereol 1986; 121: 361-2.

5. Ikeda N, Nomoto H, Hayasaka S, Nagaki Y. Phthirus pubis infestation of the eyelashes and scalp hairs in a girl. Pediatr Dermatol 2003; 20: 356-7. 